Таким образом, развитие математических знаний у дошкольников будет более эффективным при использовании всех методов в комплексе как традиционных, так и нетрадиционных. А результаты работы над математическим развитием детей будут наиболее успешны при тесном сотрудничестве педагогов детского сада и родителей, когда полученные знания в детском саду будут закрепляться дома в различных играх, задачках, головоломках, которые должны быть увлекательными, вызывающими интерес у детей.

$$
* * *
$$

1. З.А.Михайлова, М.Н.Полякова, И.Н.Чеплашкина. Математика - это интересно. Игровые ситуации для детей дошкольного возраста. 2017г.

2. Л.С. Метлина. Математика в детском саду. 1984г

3. Е.А. Носова, Р.П. Непомнящая. Логика и математика для дошкольников, 2007г.

4. В.П. Новикова. Математика в детском саду. Средний дошкольный возраст,2009г.

\title{
Доброва В.А. \\ Работа со словообразовательной моделью на уроках русского языка в начальных классах
}

\author{
ФГБОУ ВПО СГУ им. Н. Г. Чернышевского
}

(Россия, Саратов»)

doi 10.18411/spc-04-12-2017-06

idsp 000001:spc-04-12-2017-06

В настоящее время в методике преподавания русского языка появляются новые подходы, связанные с разработкой такой системы, которая наиболее эффективно решила бы задачи речевого развития школьников. Усиление внимания к содержательной стороне изучаемых явлений способствует преодолению формализма в обучении.

Особенно четко формализм наблюдается в процессе преподавания словообразования, при анализе структуры слова. В работе с производными словами внимание учащихся больше обращается на форму слова, его структуру, вне связи с его семантикой, со значением составляющих его морфем, что замедляет активизацию творческих способностей обучающихся.

Весьма эффективным способом преодоления формализма в изучении словообразования является работа со словообразовательными моделями слов. Внимание к словообразовательной модели будет способствовать углублению знаний школьников о составе слова и формированию детской грамотности. Для работы на уроках русского языка в начальной школе должны выбираться словообразовательные модели, доступные восприятию обучающихся. Исследованию данного вопроса уделяется внимание в современной системе образования.

В методических рекомендациях выделяются виды упражнений, ориентирующих на грамматический, смысловой, орфографический и морфемно-словообразовательный анализ слов через осмысление словообразовательной модели. Так, Е. Г. Мережко предлагает следующую классификацию упражнений:

1) подбор слов одной словообразовательной модели;

2) распределение слов на группы с учетом их принадлежности к той или иной словообразовательной модели;

3) выделение из контекста слов, соответствующих указанной модели; модели;

4) выделение из контекста «лишнего слова», не соответствующего заданной

5) анализ производных слов одной словообразовательной модели;

6) анализ лексического значения слов на основе словообразовательной модели и др. [Мережко: 2013]

Рассмотрим, как представлена система наблюдения за словообразовательной моделью в современных учебниках русского языка для начальной школы. Нами были 
выбраны учебники Л.Я. Желтовской и О.Б. Калининой («Планета знаний») и С.В. Иванова и др. («Начальная школа XXI века»).

В УМК "Планета знаний» изучение словообразовательной модели не предусмотрено программой. Наблюдения за словообразовательной моделью возможны уже в 1-2 классах, так как упражнения содержат необходимый для этого языковой материал, но, к сожалению, в них не предлагаются специальные вопросы и задания, направленные на анализ словообразовательной модели.

Языковой материал некоторых упражнений можно использовать для группировки слов одной словообразовательной модели. Таких заданий было найдено в учебниках больше, чем остальных.

В учебниках русского языка этой программы обнаружено 9 упражнений для организации наблюдения за словообразовательной моделью.

В учебниках русского языка программы «Начальная шккола XXI века» словообразовательная работа представлена более глубоко, шире проводятся словообразовательные наблюдения. Школьников учат производить словообразовательный анализ, на закрепление этого навыка даются задания, которые не представлены, к примеру, в учебниках программы «Планета знаний».

В учебниках русского языка данного комплекта было найдено двадцать упражнений со словообразовательными моделями. Мы распределили их по следующим группам:

1. На анализ производных слов одной модели (2 класс, 1 часть, №3 на стр. 51; №1 на стр. 107; №1 на стр. 110 и др.)

2. На образование слов, соответствующих одной модели (2 класс, 1 часть, № 3 на стр. 108; №1 на стр. 117; №1 на стр. 131, №1 на стр. 146; №4 на стр. 147; № на стр. и др.);

3. На выделение из контекста «лишнего слова», не соответствующего заданной модели (3 класс, 1 часть, №3 на стр. 86 и др.);

4. Упражнения с необходимым языковым материалом, но без специальных заданий, направленных на работу со словообразовательной моделью (2 класс, 1 часть, стр. 120; №1 на стр. 121; №4 на стр. 134; стр. 143; №3 на стр. 147; стр. 151; №3 на стр. 156) и др.

Вместе с тем единой системы упражнений со словообразовательной моделью в этом учебнике также нет, данные упражнения встречаются эпизодично.

В целом, в учебниках русского языка указанной программы представлен более богатый языковой материал, который можно использовать для работы со словообразовательной моделью. Большая часть из них находится в учебниках второго класса, так как именно во втором классе изучается состав слова и словообразование полностью.

В качестве примера рассмотрим упражнение 3 на стр. 128:

Можно ли сказать, что в словах каждой группь один и тот же суффикс? Рассуждай так: "Чайник - это предмет, в котором заваривают чай», "Школьник это тот, кто учится в школе

\begin{tabular}{|c|c|c|}
\hline 1) -ник- & & $-н и \kappa-$ \\
\hline чайник & $?$ & дворник \\
\hline цзветник & $?$ & школьник \\
\hline 2) -чик- & & -чик- \\
\hline барабанчик & $?$ & летчик \\
\hline карманчик & $?$ & перевозчик \\
\hline 3) -uk- & & $-u \kappa-$ \\
\hline котик & $?$ & химик \\
\hline ротик & $?$ & умник \\
\hline
\end{tabular}

Какой ответ ты считаешь правильным: «Эти суффиксы одинаковые, потому что пишутся одинаково» или «Эти суффиксы разные, потому что имеют разное значение»?

Это упражнение помогает детям отличать омонимичные суффиксы. Ведется работа над значением и разграничением суффиксов, подготавливает к работе со словообразовательной моделью. 
Проанализировав два комплекта учебников, мы можем сделать следующие выводы. В современных программах по русскому языку для начальной школы не выстроена система упражнений со словообразовательной моделью, однако языковой материал учебников при правильном подборе дополнительных заданий к упражнениям может способствовать формированию у детей способности чувствовать в слове словообразовательную модель и умения работать с ней.

Приведем примеры дополнительных заданий для работы со словообразовательной моделью к упражнениям в учебниках русского языка программы «Планета Знаний»

1) К Упражнению №35 (русский язык, 2 класс, 2 часть):

Бутончик, вагончик, бидончик; каменщик, бетонщик, бантик, винтик, зонтик, гвоздик, песня, ветви.

Разделите слова на группы. По какому признаку вы это сделаете? Дополните каждую группу 1-2 словами.

2) К упражнению №12 из учебника 3 класса 2 часть:

Маленький, ленточка, учитель, пекарь, беленький, каменщик, кофточка, мягонький, летчик, березонька, ситечко, наборщик.

Какие слова образованы одинаково, относятся к одной словообразовательной модели?

Таким образом, работа со словообразовательными моделями необходима в начальной школе. Выполняя словообразовательные упражнения, школьники учатся соотносить общее и частное в языке (словообразовательную модель и строение, значение, грамматические признаки конкретного слова), предвидеть возможные орфографические затруднения, вызванные структурными особенностями слов одной словообразовательной модели. При этом активизируется зрительная память ученика, лучше запоминается графический облик многих морфем, что помогает в овладении орфографическими нормами.

1. Желтовская, Л.Я., Калинина, О.Б. Русский язык. 2 класс. Учебник. В 2 ч. / Л. Я. Желтовская, О. Б. Калинина. М., АСТ, Астрель. 2011

2. Желтовская, Л.Я., Калинина, О.Б. Русский язык. 3 класс. Учебник. В 2 ч. / Л. Я. Желтовская, О. Б. Калинина. М., АСТ, Астрель. 2011

3. Мережко, Е. Г. Словарик близкородственных слов / Е. Г. Мережко. Москва: Флинта; Москва: Наука, 1997. $160 \mathrm{c}$.

4. Мережко, Е. Г. Содержание словообразовательной работы в начальных классах / Е. Г. Мережко // ПМНО: ПОИСК. МАСТЕРСТВО. НОВАТОРСТВО. ОПЫТ. МатериалЫ Всероссийской научнопрактической конференции. 2013. С. 85-87.

5. Русский язык : 2 класс : учебник для общеобразовательных учреждений : в 2 ч. / С. В. Иванов, М. И. Кузнецова, Л. В. Петленко и др. 3-е изд., испр. и доп. М. : Вентана Граф, 2013. 192 с.

\section{Карпова С.И., Иванова В.С. \\ Формирование основ экономических знаний у детей старшего дошкольного возраста}

Московский государственный педагогический университет (Россия, Москва»)

doi 10.18411/spc-04-12-2017-07

idsp 000001:spc-04-12-2017-07

\section{Аннотация}

В статье обоснована необходимость экономического воспитания детей, начиная с дошкольного возраста, представлены задачи и содержание основных разделов программы формирования основ экономических знаний у детей старшего дошкольного возраста. В качестве основных условий реализации программы в дошкольных образовательных организациях автор определяет: формирование у родителей воспитанников мотивации к осуществлению экономического воспитания 